\title{
DIALLEL CROSSING AMONG MAIZE POPULATIONS FOR RESISTANCE TO FALL ARMYWORM
}

\author{
María del Pilar Alvarez; José Branco de Miranda Filho²* \\ ${ }^{1}$ INTA (Instituto Nacional de Tecnología Agropecuaria) Ruta 178, km 4,5. CC 31 (2700) Pergamino, BA. Argentina. \\ ${ }^{2}$ Depto. de Genética - USP/ESALQ, C.P. 83 - CEP: 13400-970 - Piracicaba, SP. \\ ${ }^{*}$ Corresponding author <jbmirand@esalq.usp.br>
}

\begin{abstract}
Among the insects infecting the maize (Zea mays L.) crop in Brazil, the fall armyworm (Spodoptera frugiperda Smith, 1797, Lepdoptera: Noctuidae) is considered one of the most important because it causes the highest damage to yield. Genetic resistance to the fall armyworm has be an effective control strategy. The main objective of this work was to evaluate new germplasm sources for resistance to the fall armyworm, the key pest for the maize crop in Brazil. A partial diallel design between 20 varieties of Brazilian germplasm and nine exotic and semi-exotic varieties of different origin was used. The 180 crosses and 29 parental varieties along with two commercial checks were evaluated in three locations in the State of São Paulo State (Brasil). Fall armyworm resistance (FAWR) under artificial and natural infestations, grain yield (GY), and plant height (PH) were analyzed. The populations CMS14C and MIRT, and hybrid São José x MIRT showed the highest resistance, with values of 1.8, 1.7 and 1.4, respectively. Populations PMI9401 and PR91B, and the hybrid CMS14C x (B97xITU) had best yields, with 4893, 3858 and $5677 \mathrm{~kg} \mathrm{ha}^{-1}$, respectively. Heterosis ranged from $-28 \%$ to $47 \%$ for FAWR and from $-21 \%$ to $125 \%$ for GY, with mean values of $-0,43 \%$ and $31 \%$, respectively. Genotype by environment interaction was not significant for FAWR. The effects of varieties and heterosis were significant for all traits, showing that both additive and dominance effects may be important as sources of variation. For FAWR, only specific heterosis presented significance, suggesting strong genetic divergence between specific pairs of parental populations. Brasilian populations PMI9302 and São José, and the exotic population PR91B presented high performance per se, and also in croses for FAWR and GY. Crosses PMI9401 x (Cuba110 x EsalqPB1) and São José x MIRT presented high specific heterosis effects for both characters. These populations can be useful to be introgressed in maize breeding programs.
\end{abstract}

Key words: genetic resistance, partial diallel, germplasm

\section{CRUZAMENTO DIALÉLICO ENTRE POPULAÇÕES DE MILHO PARA RESISTÊNCIA À LAGARTA DO CARTUCHO}

\begin{abstract}
RESUMO: Dentre as pragas que infestam a cultura de milho (Zea mays L.) no Brasil, destaca-se a lagarta do cartucho (Spodoptera frugiperda Smith, 1797, Lepdoptera: Noctuidae), considerada como a praga chave por ser a que produz o maior dano. A utilização de cultivares resistentes constitui um método de controle eficiente. O principal objetivo deste trabalho foi a avaliação de novas fontes de germoplasma para resistência à lagarta do cartucho, praga chave da cultura de milho no Brasil. Foi utilizado um esquema dialélico parcial entre 20 populações representantes de germoplasma brasileiro e nove populações exóticas e semi-exóticas de diferentes origens. Os 180 híbridos e as 29 variedades genitoras, junto com duas testemunhas comerciais, foram avaliados em três locais no Estado de São Paulo (Brasil). Foram analizados os caracteres resistência à lagarta do cartucho (RLC), sob infestação artificial e natural, produtividade de grãos $(P G)$ e altura de planta (AP). As populações CMS14C e MIRT, e o híbrido São José x MIRT apresentaram a maior resistência, com valores de 1,8 , 1,7 e 1,4, respectivamente. As populações PMI9401 e PR91B, e o híbrido CMS14C x (B97 x ITU) tiveram a maior produtividade, com 4893, 3858 e $5677 \mathrm{~kg} \mathrm{ha}^{-1}$, respectivamente. Os valores de heterose foram de $-28 \%$ a $47 \%$ para RLC e de $-21 \%$ a $125 \%$ para $P G$, com valores médios de $-0,43 \%$ e $31 \%$, respectivamente. O caráter RLC não apresentou interação genótipo x ambiente significativa. Os efeitos de variedades e de heterose foram significativos para os três caracteres, indicando que tanto os efeitos aditivos quanto os de dominância podem ser importantes como fontes de variação. Para FAWR, somente a heterose específica foi significativa, sugerindo uma forte divergência genética entre pares específicos de populações parentais. As populações brasileiras PMI9302 e São José, e a população exótica PR91B apresentaram boa performance per se e em cruzamentos para resistência e produtividade. Os híbridos PMI9401 x (Cuba110 x ESALQ-PB1) e (São José x MIRT) apresentaram altos efeitos de heterose específica para ambos caracteres. Estes materiais podem ser promissores para sua incorporação em programas de melhoramento.

Palavras-chave: resistência genética, dialelo parcial, germoplasma
\end{abstract}

\section{INTRODUCTION}

Among the insects infecting the maize crop in Brazil, the fall armyworm (Spodoptera frugiperda Smith,
1797 ) is considered one of the most important because it causes the highest economic damage. Larvae feed mainly on leaves, reducing the photosynthetic area of the plant and affecting indirectly the grain production. Losses 
of the order of $15 \%$ to $34 \%$ have been reported, depending on the phase of the plant development (Cruz, 1995).

The use of resistant cultivars has been suggested by several authors (Sprague \& Dahms, 1972; Wiseman \& Widstrom, 1992) as an efficient and feasible method to control armyworm infestation, either by decreasing the population of insects or by increasing the efficiency of insecticide application, thus reducing the amount of chemical products and also reducing the negative impact on environment.

In spite of the great genetic variability of the maize germplasm in Brazil, little is known in relation to the genetic potential of different materials as sources of resistance to insect infestations. The characterization of germplasm and the identification of new sources of resistance to be used in the development of new commercial varieties become more important when faced to the presence or the increase of insects attacks.

Breeding for resistance to fall armyworm has had a slow development until the advent of techniques for artificial infestation that allowed uniform evaluations of large number of plants in the field. Such techniques were developed by Ortega et al. (1980) and modified by Wiseman \& Widstrom (1980). Artificial infestation has the advantage to provide more uniform levels of attack, with approximately the same number of larvae per plant. The evaluation under such conditions are really necessary when the high natural infestation does not occur in the experiment. On the other hand, there are environments where the population of insects remain at a high level every year, so that natural infestation is sufficient to assure evaluation with the desired precision. In the evaluation under field conditions, visual scales are used, which take into account the type of damage (size and number of lesions) and the damaged tissues (leaves and/ or whorl) (Carvalho, 1970; Davis et al., 1992).

The genetic base of the resistance to fall armyworm has been demonstrated to be of quantitative nature and the variation is due mainly to additive genetic effects although the presence of dominant gene action cannot be ruled out (Williams et al., 1989; Widstrom et al., 1992; Widstrom et al., 1993; Guimarães e Viana, 1994 e Williams et al., 1995). The identification of new sources of resistance must be a continuous process in any breeding program for resistance to insects aiming the introgression of new genes into the genetic base of the commercial cultivars. The incorporation of new genotypes, either local or exotic, in the evaluations increase the chances for identification of mechanisms and/or genes for resistance that were not previously available. In Brazil, several studies have been conducted for the evaluation of resistance to fall armyworm, either under natural infestation (Fornasieri Filho et al., 1980; Lara et al., 1984; Marques et al., 1988) or under artificial infestation (Viana \& Potenza, 1991; Viana \& Guimarães, 1994; Nishikawa, 1999).
The genetic potential of different materials are usually studied in controlled crosses; in this sense, the diallel mating scheme has been useful and largely used to estimate the potential value of genotypes per se, their combining ability and heterosis effects (Hallauer \& Miranda Filho, 1995). Miranda Filho \& Geraldi (1984) suggested the partial diallel cross between two fixed sets of varieties or lines, as an adaptation of the complete diallel model of Gardner \& Eberhart (1966). Geraldi \& Miranda Filho (1988) concluded that the adapted model of Gardner \& Eberhart (1966) is more informative than the partial diallel adapted from Griffing's (1956) model. The objectives of the present work were to evaluate maize germplasm from Brazil and exotic or semi-exotic germplasm for their agronomic traits and resistance to fall armyworm; to estimate genetic parameters for agronomic traits and resistance to fall armyworm using the partial diallel scheme (Miranda Filho \& Geraldi, 1984); and to select populations with high level of resistance and desirable agronomic traits to be indicated for their use in breeding programs.

\section{MATERIAL AND METHODS}

\section{Germplasm}

The identification of populations used in this work is shown in Table 1, divided in two groups: Group I, comprising 20 Brazilian populations previously introduced in the NAP (Núcleo de Apoio à Pesquisa) Project; and Group II, represented by nine exotic and semi-exotic populations of diverse origins. The 20 populations of Group I were selected for fall armyworm resistance, from 113 populations of the NAP Project, under artificial infestation (data not shown).

Exotic populations were introduced on the basis of their pattern of resistance to $S$. frugiperda or other corn borer species in their sites of origin. Some of the exotics (MIRT and PR91B) were used directly and others were previously crossed with local populations to develop semi-exotics better adapted to local conditions. Two commercial hybrids (MASTER: resistant; and P3041: susceptible) were used as checks, which were chosen as the extremes for resistant pattern from a set of 12 cultivars previously evaluated under artificial and natural infestation (data not shown).

\section{Experiments}

Populations of Group I were crossed with Group II, under partial diallel scheme suggested by Miranda Filho \& Geraldi (1984). The 211 entries (29 parental populations, 180 crosses and 2 hybrid checks) were evaluated in two locations representing three environments: [1] Piracicaba (SP), under artificial infestation; [2] Anhembi (SP), under natural infestation; and [3] Piracicaba (SP), under no infestation. The geographical coordinates, represented by latitude, longitude and altitude of the two locations are: $22^{\circ} 42^{\prime}$ South, $47^{\circ} 38^{\prime}$ 'West and $546 \mathrm{~m}$ for Piracicaba; and $22^{\circ} 48^{\prime}$ South, $48^{\circ} 07^{\prime}$ 'West and $469 \mathrm{~m}$ for Anhembi, 
Table 1 - Designation and origin of populations from the NAP Project (Group I) and exotic and semi-exotic populations (Group II).

\begin{tabular}{|c|c|c|}
\hline Code & Population & Origin \\
\hline \multicolumn{3}{|c|}{ Population of the NAP Project } \\
\hline N1 & BAlll Tusón & CNPMS $^{1}$ \\
\hline N2 & Caribeño DMR & $\mathrm{IAC}^{2}$ \\
\hline N3 & CMS 14C & CNPMS \\
\hline N4 & CMS 23 & CNPMS \\
\hline N5 & CMS 454 & CNPMS \\
\hline N6 & CMS 55 PH4 & CNPMS \\
\hline N7 & CMS 61 & CNPMS \\
\hline N8 & ESALQPB2 x ESALQPB3 Amarelo & $\mathrm{ESALQ} \mathrm{USP}^{3}$ \\
\hline N9 & ESALQPB2 x ESALQPB3 Branco & ESALQ/USP \\
\hline N10 & GUATEMALA & IAC \\
\hline N11 & IUBATÃ & IAC \\
\hline N12 & MEB & IAC \\
\hline N13 & Philippine DMR 4 & IAC \\
\hline N14 & PIRANÃO & ESALQ/USP \\
\hline N15 & PMI 9302 & IAPAR $^{4}$ \\
\hline N16 & PMI 9306 & IAPAR \\
\hline N17 & PMI 9401 & IAPAR \\
\hline N18 & São José & CNPMS \\
\hline N19 & Tuxpeño amarillo & IAC \\
\hline N20 & WP 12 & IAC \\
\hline \multicolumn{3}{|c|}{ Exotic and semi-exotic population } \\
\hline$\overline{E 1}$ & MIRT(Multiple Insect Resistance Tropical Population) & CIMMYT \\
\hline E2 & PR91B & CIMMYT \\
\hline E3 & B95 x ITU & US Corn Belt $x$ Local \\
\hline E4 & B97xITU & US Corn Belt x Local \\
\hline E5 & Population 58 & CIMMYT \\
\hline E6 & PI571676 (Madre de Dios 47) x ESALQ PB1 & Cuba $x$ Local \\
\hline E7 & PH89360 (Cuba 113) x ESALQ PB1 & Cuba $\times$ Local \\
\hline E8 & P489357 (Cuba 110) x ESALQ PB1 & Cuba $x$ Local \\
\hline E9 & Pi571833 (Libertad 179) x ESALQ PB1 & Cuba x Local \\
\hline
\end{tabular}

'CNPMS: Centro Nacional de Pesquisa de Milho e Sorgo (EMBRAPA) - Sete Lagoas, ${ }^{2}$ AC: Instituto Agronômico de Campinas, Estado de São Paulo. ${ }^{3}$ ESALQ/USP: Escola Superior de Agricultura "Luiz de Queiroz" (Universidade de São Paulo) - Piracicaba, Estado de São Paulo. ${ }^{4}$ IAPAR: Instituto Agronômico do Estado de Paraná. Londrina, Estado de Paraná.

respectively. The three environments will be here designated as experiments, symbolized by EXP [1], EXP [2] and EXP [3], respectively. A completely randomized block design was used, with one-row plots, $5 \mathrm{~m}$ long with spaces of $0.9 \mathrm{~m}$ between rows and $0.2 \mathrm{~m}$ between plants within rows; with an expected stand of 25 plants per plot after thinning. Number of replications were three in EXP [1] and EXP [3] and four in EXP [2]. Planting dates were September 23, September 22 and November 20 for EXP [1], EXP [2] and EXP [3], respectively, in 1998. Plots of the susceptible check were intercalated each 15 rows in EXP [1] and EXP [2], for observation on the uniformity of infestations and for calculating the correlation between traits.

\section{Evaluated traits}

The resistance to the fall armyworm (RFA) was evaluated in EXP [1] under artificial infestation and in
EXP [2] under natural infestation. Artificial infestation in the field was made by application of young larvae mixed with corn cob grits using a manual dispenser "bazooka" (Wiseman et al., 1980). Infestations were made in eight plants per plot in the stages V6 to V8, with approximately 15 larvae per plant. In EXP [1] visual evaluation of the damage was at 7 and 14 days after infestation. In EXP [2] the first evaluation was 7 days after the stages V6V8, following another evaluation one week later. In both experiments a scale of notes (0: non-damaged plant to 5: plant whorl completely destroyed) was used (Carvalho, 1970). Data for statistical analysis was represented by the average of two measurements, as suggested by Davis et al. (1992). Grain yield (GY: total grain weight of the plot, in $\left.\mathrm{kg} \mathrm{ha}^{-1}\right)$ and plant height ( $\mathrm{PH}$ : mean of ten plants per plot, in $\mathrm{cm}$ ) were also included for analysis of EXP [2] and EXP [3]. 


\section{Statistical analysis}

Preliminary analysis of variance for each experiment and combined analysis over experiments were performed for all traits. The analysis of variance of the partial diallel tables combined over experiments followed the model (Miranda Filho \& Geraldi, 1984; Belluci, 1994):

$Y_{i j k}=\mu+\alpha\left[d+(I d)_{k}\right]+1 / 2\left[v_{i}+v_{i}+(I V)_{i k}+(I V)_{j k}\right]+I_{k}$ $+\theta\left[\bar{h}+h_{i}+h_{j}+s_{i j}+(1 \bar{h})_{k}+(l h)_{i k}+(I h)_{j k}+(I s)_{i j k}+\bar{e}_{i j k}\right.$

where $Y_{i j k}$ is the mean of the cross between $i^{\text {th }}$ population (Group ${ }^{\text {I }}$ ) and $j^{\text {th }}$ population (Group II) in the $k^{\text {th }}$ experiment; $\mu$ is the mean of the two groups; $\alpha=1, \alpha=-$ 1 and $\alpha=0$ for parental varieties of groups I and II and crosses, respectively; $d$ is a measure of the difference between group means; $v_{i}$ and $v_{i}$ are the effects of populations for Groups I and II, respectively; $I_{k}$ is the fixed effect of experiments; $\theta=0$ for parental populations $\left(Y_{i i}\right.$ and $\left.Y_{i j}\right)$ and $\theta=1$ for crosses $\left(Y_{i j}\right)$; $\bar{h}$ is the average heterosis over experiments; $h_{i}$ and $h_{i}$ are the effects of heterosis of populations for Groups I and II, respectively; $S_{i j}$ is the specific heterosis of the cross $i x j ; \bar{e}_{i j k}$ is the error term associated to the observed mean $\left(Y_{i i}, Y_{i j}\right.$ or $\left.Y_{i j}\right)$ in the $k^{\text {th }}$ experiment; all other terms in the model refer to the interaction of the respective effects with experiments (environments).

\section{RESULTS AND DISCUSSION}

Observed means are presented for three traits: RFA, combined for EXP. [1] and EXP. [2]; GY for EXP. [2] and EXP. [3] and PH combined for EXP. [2] and EXP. [3] (Table 2).

\section{Preliminary analyses of variance}

The preliminary analysis of variance, combined over experiments (data not shown), revealed differences between the hybrid checks for the variable RFA, indicating the effectiveness of the conditions of infestation for the discrimination between genotypes. Also, the nonsignificance of the interaction checks $x$ experiments indicated that the reaction of the hybrid checks was relatively stable, even though the level of incidence of $S$. frugiperda was different between experiments. The non significance of the treatment $x$ experiment interaction also reinforce the stable response of genotypes under the two different conditions of infestation.

For the variable GY significance was detected for both treatments and treatment $x$ experiment interaction, indicating results should be interpreted for each experiment representing different environments. A similar pattern of significance was observed for the variable $\mathrm{PH}$, but the mean square for treatments was 6.6 times greater than for the interaction treatment $x$ experiment; although significant, the later showed a lower level of variation, as indicated by the $\mathrm{F}$ test $(\mathrm{F}=1.4)$. For that reason, all parameters for $\mathrm{PH}$ were calculated with the mean over experiments.

\section{Analysis of the diallel tables}

Table 3 shows the analyses of variance for the three variables for the partial diallel table, represented by observed means of parental populations and their crosses. Differences were observed between groups for RFA $(P<0.01)$ and $\mathrm{PH}(P<0.05)$. For RFA the difference was for advantage of Group II (lower mean) with an estimated parameter of $d=0.162$. This result is explained by the fact that the NAP populations (Group I) were chosen for their pattern of resistance to $S$. frugiperda but, except for CMS14C, CMS23 and São José, all other were never submitted to selection for resistance. On the other hand, the exotic populations (Group II) were released for their high pattern of resistance to $S$. frugiperda and other Lepdoptera species.

Populations N3 (CMS14C) and E1 (MIRT), and the cross N18 (São José) x E1 (MIRT) presented highest resistance, with values of $1.8,1.7$ and 1.4 , respectively. Populations PMI9401 and PR91B, and hybrid CMS14C $x$ (B97xITU) had best yields, with 4893, 3858 and $5677 \mathrm{~kg} \mathrm{ha}^{-1}$, respectively (Table 2). Genotype by environment interaction was not significant for FAWR (Table 3).

Heterosis showed significance $(P<0.01)$ for all traits. For RFA the significant components of heterosis were population heterosis in Group I and specific heterosis; $\overline{\mathrm{h}}=-1.04 \%$ ) indicated non unidirectional dominance effects (Vencovsky \& Barriga, 1992), which can be explained by the presence of different mechanisms of resistance, under the control of different genetic systems. In fact, the heterosis effects in crosses varied from negative $(-28 \%)$ to positive $(47 \%)$ in the crosses N14 $x$ E3 and N3 $\times$ E3, respectively (Table 4). For GY and PH all the heterosis components showed significance.

The significance for GY heterosis variation is explained by the wide range of estimates, which varied from $-20.0 \%(\mathrm{~N} 12 \times \mathrm{E} 6)$ to $138.3 \%$ (N14 x E5) and from $23.0 \%(\mathrm{~N} 12 \times \mathrm{E} 6)$ to $114.1 \%$ (N14 $\times$ E3) in EXP 2 and EXP 3, respectively (Table 5). Mid-parent heterosis higher than $20 \%$ was represented by $64 \%$ and $68 \%$ of the crosses in EXP 2 and EXP 3, respectively. Hallauer \& Miranda Filho (1995) reported heterosis of $19.5 \%$ on the average of crosses involving 611 different parental varieties. High heterosis suggests a high concentration of homozygotes, as expected in races or populations continuously maintained through small population size (Miranda Filho, 1999). However, the lack of adaptation also may result in a low performance of the parental population and, if the other parent allows the recovery of an acceptable pattern of adaptation, the final result may be the expression of a high heterosis (Regitano Neto \& Miranda Filho, 1999). Heterosis for PH is of lesser interest for a breeding programs and it has shown low expresion in population crosses (Hallauer \& Miranda Filho, 1995). Observations (data not shown) indicated heterosis varying from $-11.8 \%$ to $26.4 \%$ and only $16 \%$ of the crosses showed mid-parent heterosis higher than $10 \%$. 
Table 2 - Observed means for resistance to fall armyworm (RFA), grain yield (GY) and plant height (PH) for populations and crosses.

\begin{tabular}{|c|c|c|c|c|c|c|c|c|c|}
\hline CODE & RFA & $G Y_{E 2}$ & $\mathrm{GY}_{\mathrm{E} 3}$ & $\mathrm{PH}$ & CODE & RFA & $G Y_{E 2}$ & $\mathrm{GY}_{\mathrm{E} 3}$ & $\mathrm{PH}$ \\
\hline N1 & 2.5 & 1847 & 2015 & 179 & N1xE8 & 2.4 & 4544 & 4333 & 200 \\
\hline N2 & 2.6 & 3081 & 3307 & 180 & N1xE9 & 2.1 & 3378 & 2359 & 189 \\
\hline N3 & 1.8 & 4236 & 3111 & 189 & N2xE1 & 1.9 & 4089 & 4356 & 179 \\
\hline N4 & 2.1 & 3656 & 2811 & 173 & N2xE2 & 2.1 & 4292 & 3326 & 179 \\
\hline N5 & 2.3 & 5031 & 3896 & 181 & N2xE3 & 1.8 & 3603 & 3859 & 188 \\
\hline N6 & 2.7 & 3374 & 3033 & 194 & N2xE4 & 2.1 & 5142 & 4026 & 189 \\
\hline N7 & 3 & 3558 & 3363 & 180 & N2xE5 & 2.2 & 3169 & 3493 & 175 \\
\hline N8 & 2.1 & 4011 & 3700 & 181 & N2xE6 & 2.4 & 3236 & 2619 & 202 \\
\hline N9 & 1.9 & 4769 & 3437 & 186 & N2xE7 & 2 & 3389 & 3093 & 201 \\
\hline N10 & 2.3 & 3814 & 2670 & 180 & N2xE8 & 2.4 & 4258 & 3222 & 199 \\
\hline N11 & 2.5 & 3714 & 3304 & 188 & N2xE9 & 2.6 & 3372 & 2593 & 187 \\
\hline N12 & 2.4 & 4603 & 3126 & 235 & N3xE1 & 1.7 & 4925 & 4485 & 186 \\
\hline N13 & 2.1 & 2894 & 2170 & 182 & N3xE2 & 1.6 & 5125 & 3352 & 189 \\
\hline N14 & 2.9 & 2239 & 1989 & 160 & N3xE3 & 2.7 & 4961 & 3304 & 187 \\
\hline N15 & 1.8 & 4111 & 3156 & 188 & N3xE4 & 2.3 & 6769 & 4585 & 202 \\
\hline N1 6 & 2.3 & 4469 & 2848 & 186 & N3xE5 & 1.8 & 4081 & 2574 & 182 \\
\hline N17 & 2 & 5217 & 4570 & 198 & N3xE6 & 2.3 & 4922 & 4206 & 228 \\
\hline N1 8 & 2.3 & 4756 & 4304 & 209 & N3xE7 & 1.7 & 4847 & 3604 & 210 \\
\hline N19 & 2.5 & 4114 & 3356 & 163 & N3xE8 & 2.2 & 5450 & 3737 & 205 \\
\hline N20 & 2.1 & 4350 & 3378 & 195 & N3xE9 & 2.3 & 5131 & 3844 & 200 \\
\hline E1 & 1.7 & 2953 & 2433 & 165 & N4xE1 & 2.4 & 4208 & 3422 & 178 \\
\hline E2 & 1.7 & 4050 & 3667 & 186 & N4xE2 & 1.5 & 4525 & 4533 & 192 \\
\hline E3 & 2 & 2333 & 1519 & 165 & N4xE3 & 1.7 & 5194 & 3593 & 200 \\
\hline E4 & 1.9 & 4342 & 3089 & 181 & N4xE4 & 2 & 5131 & 3541 & 193 \\
\hline E5 & 2 & 1697 & 1826 & 148 & N4xE5 & 1.8 & 3404 & 3226 & 180 \\
\hline E6 & 2 & 4042 & 2515 & 216 & N4xE6 & 1.9 & 3992 & 3141 & 213 \\
\hline E7 & 2.1 & 3489 & 3256 & 221 & N4xE7 & 1.6 & 4408 & 4333 & 208 \\
\hline E8 & 2.4 & 3864 & 3722 & 207 & N4xE8 & 1.8 & 3956 & 3196 & 192 \\
\hline E9 & 2.1 & 3056 & 1874 & 185 & N4xE9 & 2.1 & 3825 & 3522 & 176 \\
\hline N1xE1 & 2.3 & 4003 & 3104 & 188 & N5xE1 & 1.7 & 4547 & 3970 & 178 \\
\hline N1xE2 & 1.8 & 4081 & 2459 & 186 & N5xE2 & 2.1 & 4561 & 4030 & 175 \\
\hline N1xE3 & 1.7 & 4772 & 3215 & 191 & N5xE3 & 1.6 & 5203 & 3844 & 182 \\
\hline N1xE4 & 2.3 & 4244 & 3778 & 186 & N5xE4 & 2 & 5331 & 4374 & 185 \\
\hline N1xE5 & 2.4 & 3550 & 2933 & 181 & N5xE5 & 2 & 4947 & 3915 & 192 \\
\hline N1xE6 & 2.1 & 4242 & 3433 & 220 & N5xE6 & 2.5 & 4817 & 4467 & 215 \\
\hline N1xE7 & 1.8 & 3861 & 3389 & 214 & N5xE7 & 1.8 & 4414 & 3933 & 191 \\
\hline N5xE8 & 2.4 & 5492 & 5133 & 204 & N9xE8 & 2 & 5192 & 4033 & 203 \\
\hline N5xE9 & 2.3 & 4592 & 3726 & 179 & N9xE9 & 2.8 & 4689 & 2996 & 184 \\
\hline N6xE1 & 2.1 & 3969 & 3019 & 173 & N10xE1 & 2.6 & 4683 & 3330 & 180 \\
\hline N6xE2 & 2 & 4628 & 3633 & 179 & N10xE2 & 2 & 5183 & 4130 & 185 \\
\hline N6xE3 & 2.2 & 4700 & 4085 & 198 & N10xE3 & 2 & 4575 & 3315 & 183 \\
\hline N6xE4 & 2.5 & 5558 & 3974 & 191 & N10xE4 & 2.4 & 5564 & 4867 & 193 \\
\hline N6xE5 & 2.6 & 4814 & 3400 & 186 & N10xE5 & 2.1 & 3150 & 3615 & 165 \\
\hline N6xE6 & 2.3 & 4339 & 4244 & 216 & N10xE6 & 2.3 & 4108 & 4174 & 204 \\
\hline N6xE7 & 1.9 & 4283 & 4230 & 204 & N10xE7 & 1.8 & 4294 & 3763 & 191 \\
\hline N6xE8 & 1.91 & 4830 & 3974 & 195 & N10xE8 & 1.9 & 3914 & 3944 & 194 \\
\hline N6xE9 & 2.57 & 3800 & 3589 & 189 & N10xE9 & 2.2 & 4183 & 3648 & 180 \\
\hline N7xE1 & 2.15 & 4589 & 3567 & 181 & N11xE1 & 2.2 & 4756 & 4096 & 171 \\
\hline N7xE2 & 2.25 & 4436 & 4089 & 179 & N11xE2 & 2.4 & 5406 & 4496 & 193 \\
\hline N7xE3 & 2.07 & 4800 & 3300 & 192 & N11xE3 & 1.7 & 4703 & 3056 & 185 \\
\hline N7xE4 & 2.34 & 5031 & 3874 & 189 & N11xE4 & 2 & 5078 & 4019 & 181 \\
\hline N7xE5 & 1.99 & 4308 & 3252 & 170 & N11xE5 & 1.8 & 4686 & 4204 & 179 \\
\hline N7xE6 & 2.1 & 4481 & 4452 & 207 & N11xE6 & 2 & 4833 & 4370 & 221 \\
\hline N7xE7 & 2.47 & 4585 & 4693 & 202 & N11xE7 & 2.5 & 5419 & 3326 & 210 \\
\hline N7xE8 & 2.52 & 4556 & 4270 & 210 & N11xE8 & 2.2 & 5072 & 3374 & 211 \\
\hline N7xE9 & 2.29 & 3537 & 3833 & 179 & N11xE9 & 2.1 & 4231 & 3352 & 191 \\
\hline
\end{tabular}




\begin{tabular}{|c|c|c|c|c|c|c|c|c|c|}
\hline N8xE1 & 2.15 & 4308 & 4044 & 182 & N12xE1 & 1.6 & 4706 & 2885 & 211 \\
\hline N8xE2 & 1.84 & 5133 & 4578 & 176 & N12xE2 & 1.9 & 5614 & 3200 & 200 \\
\hline N8xE3 & 2.26 & 5272 & 2963 & 188 & N12xE3 & 1.9 & 5208 & 3293 & 207 \\
\hline N8xE4 & 2.35 & 5108 & 4867 & 186 & N12xE4 & 2.1 & 5306 & 3652 & 211 \\
\hline N8xE5 & 1.71 & 3767 & 3981 & 185 & N12xE5 & 1.7 & 5042 & 3378 & 212 \\
\hline N8xE6 & 2.1 & 4628 & 3178 & 225 & N12xE6 & 2.7 & 3456 & 2170 & 252 \\
\hline N8xE7 & 2.81 & 4275 & 3804 & 198 & N12xE7 & 2.1 & 4433 & 4363 & 239 \\
\hline N8xE8 & 2.12 & 5069 & 3930 & 190 & N12xE8 & 2.1 & 4756 & 4185 & 217 \\
\hline N8xE9 & 2.69 & 4164 & 3374 & 186 & N12xE9 & 2.8 & 4556 & 3174 & 205 \\
\hline N9xE1 & 2.12 & 5019 & 3948 & 186 & $\mathrm{~N} 13 x \mathrm{E} 1$ & 2.2 & 4472 & 2893 & 176 \\
\hline N9xE2 & 2.35 & 5186 & 4489 & 188 & N13xE2 & 2.2 & 4419 & 3578 & 183 \\
\hline N9xE3 & 1.55 & 3967 & 3133 & 187 & N13xE3 & 2.2 & 3567 & 3015 & 175 \\
\hline N9xE4 & 2 & 5625 & 3493 & 193 & N13xE4 & 2 & 5250 & 3893 & 201 \\
\hline N9xE5 & 2.02 & 4486 & 3256 & 185 & N13xE5 & 1.9 & 4003 & 3593 & 174 \\
\hline N9xE6 & 2.24 & 4733 & 3344 & 212 & N13xE6 & 2.4 & 3792 & 3607 & 216 \\
\hline N9xE7 & 1.71 & 4239 & 3659 & 201 & N13xE7 & 2.8 & 3669 & 4230 & 203 \\
\hline N13xE8 & 2.1 & 4408 & 4122 & 205 & N17xE8 & 2 & 4556 & 4270 & 218 \\
\hline N13xE9 & 2.7 & 4608 & 2907 & 193 & N17xE9 & 2.7 & 3537 & 3833 & 196 \\
\hline N14xE1 & 2 & 5136 & 4544 & 201 & N18xE1 & 1.4 & 4308 & 4044 & 195 \\
\hline N14xE2 & 2 & 4350 & 2611 & 196 & N18xE2 & 2.1 & 5133 & 4578 & 202 \\
\hline N14xE3 & 1.8 & 5319 & 3756 & 198 & N18xE3 & 2.1 & 5272 & 2963 & 185 \\
\hline N14xE4 & 2.1 & 4472 & 3789 & 189 & N18xE4 & 2 & 5108 & 4867 & 200 \\
\hline N14xE5 & 2.3 & 4689 & 3037 & 195 & N18xE5 & 1.8 & 3767 & 3981 & 197 \\
\hline N14xE6 & 2.6 & 4250 & 2741 & 230 & N18xE6 & 2.5 & 4628 & 3178 & 209 \\
\hline N14xE7 & 2.3 & 3644 & 3526 & 213 & N18xE7 & 2 & 4275 & 3804 & 222 \\
\hline N14xE8 & 2.3 & 5569 & 4407 & 219 & N18xE8 & 1.95 & 5031 & 4556 & 219 \\
\hline N14xE9 & 2.3 & 4908 & 3081 & 196 & N18xE9 & 2.2 & 4211 & 3326 & 181 \\
\hline N15xE1 & 1.5 & 4314 & 4056 & 178 & N19xE1 & 1.96 & 3803 & 4074 & 171 \\
\hline N15xE2 & 2.1 & 5225 & 3800 & 177 & N19xE2 & 2.13 & 5264 & 3504 & 170 \\
\hline N15xE3 & 2.2 & 5508 & 4048 & 188 & N19xE3 & 1.82 & 5003 & 3448 & 175 \\
\hline N15xE4 & 2.2 & 5589 & 3085 & 174 & N19xE4 & 2.48 & 6006 & 4693 & 179 \\
\hline N15xE5 & 1.8 & 4094 & 3304 & 187 & N19xE5 & 2.04 & 4256 & 3441 & 172 \\
\hline N15xE6 & 2.2 & 4464 & 4752 & 215 & N19xE6 & 2.14 & 4111 & 4263 & 204 \\
\hline N15xE7 & 1.6 & 4836 & 3819 & 202 & N19xE7 & 1.81 & 3953 & 3556 & 195 \\
\hline N15xE8 & 2.1 & 5492 & 5133 & 206 & N19xE8 & 2.3 & 5011 & 3800 & 190 \\
\hline N15xE9 & 1.9 & 4592 & 3726 & 189 & N19xE9 & 2.46 & 3200 & 2626 & 177 \\
\hline N16xE1 & 1.8 & 3969 & 3019 & 183 & N20xE1 & 2.11 & 5636 & 4367 & 182 \\
\hline N16xE2 & 2.1 & 4628 & 3633 & 172 & N20xE2 & 2.17 & 5167 & 3944 & 168 \\
\hline N16xE3 & 2.4 & 4700 & 4085 & 191 & N20xE3 & 2.19 & 5553 & 3533 & 189 \\
\hline N16xE4 & 2 & 5558 & 3974 & 183 & $\mathrm{~N} 20 \times \mathrm{E} 4$ & 1.94 & 6050 & 4374 & 203 \\
\hline N16xE5 & 1.6 & 4814 & 3400 & 175 & N20xE5 & 1.83 & 4831 & 3552 & 191 \\
\hline N16xE6 & 2.4 & 4339 & 4244 & 218 & N20xE6 & 2.83 & 4728 & 3770 & 220 \\
\hline N16xE7 & 1.7 & 4283 & 4230 & 201 & N20xE7 & 2.53 & 4969 & 3996 & 196 \\
\hline N16xE8 & 2.5 & 4830 & 3974 & 205 & N20xE8 & 2.09 & 6086 & 4841 & 202 \\
\hline N16xE9 & 2.1 & 3800 & 3589 & 178 & N20xE9 & 2.15 & 5733 & 3333 & 188 \\
\hline N17xE1 & 2.2 & 4589 & 3567 & 166 & Mean & 2.14 & 4486 & 3634 & 192.7 \\
\hline N17xE2 & 2.7 & 4436 & 4089 & 191 & Max & 3.00 & 6769 & 5133 & 251.7 \\
\hline N17xE3 & 2.7 & 4800 & 3300 & 191 & Min & 1.40 & 1697 & 1519 & 147.7 \\
\hline N17xE4 & 1.8 & 5031 & 3874 & 194 & $\mathrm{H}_{\mathrm{R}}$ & 1.97 & 5706 & 4567 & 186.8 \\
\hline N17xE5 & 2.2 & 4308 & 3252 & 179 & $\mathrm{H}_{\mathrm{S}}$ & 3.00 & 6847 & 4774 & 197.3 \\
\hline N17xE6 & 2.3 & 4481 & 4452 & 226 & --- & --- & --- & --- & --- \\
\hline N17xE7 & 2.4 & 4585 & 4693 & 207 & --- & --- & --- & --- & --- \\
\hline
\end{tabular}

RFA - means of two experiments (environments) in notes from 0 to 5 (see text).

$\mathrm{GY}_{\mathrm{E} 1}$ and $\mathrm{GY}_{\mathrm{E} 3}$ : means in $\mathrm{kg} \mathrm{ha}^{-1}$ for EXP 2 and EXP 3, respectively.

$\mathrm{PH}$ : mean of two experiments (EXP 2 and EXP 3). 
Interactions of effects with experiments were nonsignificant for RFA and AP (except populations I $\mathrm{x}$ experiments); for GY all the effects presented interaction with experiments.

Dominance effects can be an important source of variation for all traits. The relative contribution of each source of variation to the total sum of squares shows that dominance effects are differentiated among the studied traits. For RFA $32 \%$ of the total sum of squares are due to the variation of populations while $68 \%$ are attributed to the total heterosis; specific heterosis is responsible for $84 \%$ of the total variation of heterosis. For similar situations, Miranda Filho \& Vencovsky (1984) considered that even if the additive and dominance effects are confounded in the effects of populations ( $v_{i}$ and $v_{i}$ ), it is reasonable to suppose that the dominance effects are more expressive at the interpopulation (population cross) level. The detection of dominance effects in the control of the resistance to $S$. frugiperda was already reported by Williams et al. (1978), Widstrom et al. (1993), Guimarães \& Viana (1994), and Williams et al. (1995). For GY and PH, the proportion of the variation due to populations and heterosis were 46.9 : 53.1 and $77.8: 22.2$, indicating that the dominance at the interpopulation level is more expressive for GY than for $\mathrm{PH}$. Similar results were reported by Miranda Filho \& Vencovsky (1984) and Santos et al. (1994). Low heterotic response for $\mathrm{PH}$ has also been reported by many authors (Castro et al. 1968; Barriga e Vencovsky, 1973; Souza, Jr., 1981; Miranda Filho \& Vencovsky, 1984).

The estimates of the effects $\left(\mu, d, v_{i}, v_{i}, \bar{h}, h_{i}, h\right.$; except $s_{i j}$ ) in the partial diallel model are presented in Table 6 for RFA and PH and in Table 7 for GY for both experiments. The effect of general combining ability (GCA) was estimated by $g=\frac{1}{2} v_{i}+h_{i}$ and $g=\frac{1}{2} v_{i}+h_{i}$ (Geraldi \& Miranda Filho, 1988). Outstanding populations in Group I for GCA (negative $g_{i}$ ) of RFA were N4 (CMS23), N15 (PMI9302) and N18 (Tuxpeño Amarelo). CMS23 is a population that had undergone selection at EMBRAPA under artificial selection and was released for its good level of resistance to $S$. frugiperda. Results observed in the present work allowed the identification of populations, as mentioned above, to be used as source of resistance at levels similar to CMS23.

In Group II, two populations from CIMMYT (E1 MIRT and E2- PR91B) exhibited the best values for resistance (negative $v_{j}$ ). The use of $v_{j}$ instead of $g_{j}$ (Table 4) for discriminating the best populations is explained by the non significance of population heterosis effects. MIRT (Multiple Insect Resistance for Tropical Regions) was selected at CIMMYT (Smith et al., 1989) and released for its high resistance to several species of the family Lepdoptera (Ostrinia nubilalis, Diatraea saccharalis, D. grandiosella, and S. frugiperda). PR91B is a population selected at CIMMYT (Colombia) for resistance to $S$. frugiperda.
For GY the highest GCA effects in EXP 2 were observed for N20 (WP12), N3 (CMS14C) and N17 (PMI9401) in Group I and for E4 (B97 x ITU), E8 (Cuba $110 \times$ ESALQ PB1), E2 (PR91B) and E3 (B95 x ITU) in Group II. In EXP 3 the highest GCA effects were for N17 (PMI9401), N5 (CMS454), N18 (São José) and N20 (WP12) in Group I and E8 (Cuba110 x ESALQPB1), E4 (B97 x ITU), E2 (PR91B) and E7 (Cuba113 x ESALQPB1) in Group II.

Regarding $\mathrm{PH}$, low estimates are desired if the objective is to identify populations with lower plant height and ear height, as generally occur with tropical germplasm. Lower estimates of GCA were obtained for N19 (Tuxpeño amarillo), N10 (Guatemala), N2 (Caribeño DMR), N5 (CMS454) and N16 (PMI9306) in Group I; and for populations E1 (MIRT), E5 (Pop. 58), E2(PR91B) and E9(Libertad179 x ESALQPB1) in Group II.

\section{Selection of populations}

Heterosis in variety crosses can be used directly in the first generation of the cross between two parental varieties. The parental populations of heterotic crosses also can be used for the development of inbred lines to be used in hybrid crosses. On the other hand, the synthesis of composites by intercrossing $n$ parental varieties is a mean to retain heterosis in the population, because $(n-1) / n$ of the heterosis component remain as part of the expected mean of the new population (Miranda Filho \& Vencovsky, 1984).

In the present work, expressive heterosis effects were detected for both RFA and GY, which can be utilized by selecting the outstanding crosses. The effects of varieties or populations also were detected in both groups of populations and selection based on this parameter leads to the identification of the most appropriate populations for intrapopulation recurrent selection.

The correlation coefficients between RFA and GY, calculated from measurements of the hybrid check, planted every fifteen rows in the experiments, were non significant: $r=-11 \%, P=0.46$ under artificial infestation; and $r=-1,4 \%, P=0.92$ under natural infestation. For this reason, selection of populations based only on $G Y$ is not recommended and, both traits (RFA and GY) must be taken into account.

Populations N4 (CMS23), N15 (PMI9302) and N18 (São José) from Group I, and E1 (MIRT) and E2 (PR91B), from Group II, showed the best performance for RFA in crosses. The good resistance level of crosses between these two selected groups is explained by the fact that N4, N15 and N18 exhibited the best estimates of $g_{i}$ in Group I and E1 and E2 showed the best level of resistance per se $\left(v_{i}\right)$ in Group II.

For GY an analysis for each experiment (environment) was necessary because the existence of genotype $x$ experiment interaction. In EXP 2, N4 did not presented a good performance in relation to GCA effect $\left(g_{\mathrm{i}}\right)$, while N15 and N18 showed good levels for GCA. In 
Table 3 - Mean squares and their significance in the analyses of diallel tables for the variables RFA, GY and PH combined over experiments.

\begin{tabular}{|c|c|c|c|c|}
\hline & & RFA & $G Y^{1}$ & $\mathrm{PH}$ \\
\hline Source of variation & $G L$ & & Mean square & \\
\hline Dialelll & 208 & $0.6753^{* *}$ & $28.660^{* *}$ & $1762.47^{\text {** }}$ \\
\hline Groups & 1 & 5.7230 ** & $2.760 \mathrm{~ns}$ & 1107.04 * \\
\hline Populations (I) & 19 & 1.0460 ** & $76.979^{\star *}$ & $4506.65^{* *}$ \\
\hline Populations (II) & 8 & $2.4401^{\star *}$ & 166.534 ** & 24799.49 ** \\
\hline Heterosis & 180 & $0.5297^{\star *}$ & $17.575^{* *}$ & $452.58^{* \star}$ \\
\hline Average heterosis & 1 & $0.0756 \mathrm{~ns}$ & 134.009 ** & 8671.46 ** \\
\hline Population heterosis (I) & 19 & $0.5745^{* *}$ & 12.509 ** & $762.61^{* *}$ \\
\hline Population heterosis (II) & 8 & $0.4804 \mathrm{~ns}$ & $18.475^{* \star}$ & 1034.06 ** \\
\hline Specific heterosis & 152 & $0.5297^{\star *}$ & 9.460 ** & $329.15^{* *}$ \\
\hline Dialell x Experiments (E) & 208 & 0.2999 ns & $8.080^{* *}$ & $265.17^{\star \star}$ \\
\hline Between experiments & 1 & --- & $16.229 \mathrm{~ns}$ & $74.89 \mathrm{~ns}$ \\
\hline Populations (I) $\times \mathrm{E}$ & 19 & --- & $2787.904^{* \star}$ & $872.83^{* *}$ \\
\hline Populations (II) $\times \mathrm{E}$ & 8 & --- & 6692.450 ** & $357.51 \mathrm{~ns}$ \\
\hline Heterosis $\times \mathrm{E}$ & 180 & --- & $5.647^{\star \star}$ & $197.98 \mathrm{~ns}$ \\
\hline Avg. heterosis $\times E$ & 1 & --- & $43841.062^{* *}$ & $608.33 \mathrm{~ns}$ \\
\hline Pop. heterosis $(\mathrm{I}) \times \mathrm{E}$ & 19 & --- & $412.727^{\star \star}$ & 239.83 ns \\
\hline Pop. heterosis (II) $\times E$ & 8 & --- & $403.075^{\star \star}$ & $284.72 \mathrm{~ns}$ \\
\hline Specific heterosis $\times \mathrm{E}$ & 152 & --- & $5.127 \mathrm{~ns}$ & $185.48 \mathrm{~ns}$ \\
\hline Pooled error & 1050 & 0.2917 & 4.372 & 183.84 \\
\hline
\end{tabular}

${ }^{\star *},{ }^{*}, \mathrm{~ns}$ - significance levels for the $\mathrm{F}$ test: $P<0.01, P<0.05$ and non significant, respectively. ${ }^{1}$ Mean squares multiplied by $10^{-5}$

Table 4 - Estimates of total heterosis ( $h_{\mathrm{iji}}$ : upper valuer) and specific heterosis ( $\mathrm{s}_{\mathrm{ij}}$ : lower values) for RFA in population crosses.

\begin{tabular}{|c|c|c|c|c|c|c|c|c|c|}
\hline & E1 & E2 & E3 & E4 & E5 & E6 & E7 & E8 & E9 \\
\hline \multirow[t]{2}{*}{ N1 } & 9.5 & -14.3 & -24.4 & 4.5 & 6.7 & -6.7 & -21.7 & -2.0 & -8.7 \\
\hline & 0.35 & -0.21 & -0.27 & 0.18 & 0.42 & -0.23 & -0.26 & 0.29 & -0.27 \\
\hline \multirow[t]{2}{*}{ N2 } & -11.6 & -2.3 & -21.7 & -6.7 & -4.3 & 4.3 & -14.9 & -4.0 & 10.6 \\
\hline & -0.13 & -0.04 & -0.29 & -0.12 & 0.15 & 0.06 & -0.06 & 0.19 & 0.24 \\
\hline \multirow[t]{2}{*}{ N3 } & -2.9 & -8.6 & 42.1 & 24.3 & -5.3 & 21.1 & -12.8 & 4.8 & 17.9 \\
\hline & -0.24 & -0.37 & 0.77 & 0.21 & -0.07 & 0.05 & -0.34 & 0.05 & -0.05 \\
\hline \multirow[t]{2}{*}{ N4 } & 26.3 & -21.1 & -17.1 & 0.0 & -12.2 & -7.3 & -23.8 & -20.0 & 0.0 \\
\hline & 0.63 & -0.3 & -0.04 & 0.16 & 0.03 & -0.15 & -0.21 & -0.15 & 0.04 \\
\hline \multirow[t]{2}{*}{ N5 } & -15.0 & 5.0 & -25.6 & -4.8 & -7.0 & 16.3 & -18.2 & 2.1 & 4.5 \\
\hline & -0.25 & 0.1 & -0.31 & -0.1 & 0.07 & 0.3 & -0.16 & 0.32 & 0.02 \\
\hline \multirow[t]{2}{*}{ N6 } & -4.5 & -9.1 & -6.4 & 8.7 & 10.6 & -2.1 & -20.8 & -25.1 & 7.1 \\
\hline & -0.02 & -0.14 & 0.05 & 0.26 & 0.5 & -0.13 & -0.28 & -0.35 & 0.12 \\
\hline \multirow[t]{2}{*}{ N7 } & -8.5 & -4.3 & -17.2 & -4.5 & -20.4 & -16.0 & -3.1 & -6.7 & -10.2 \\
\hline & 0.02 & 0.06 & -0.08 & 0.08 & -0.11 & -0.34 & 0.3 & 0.24 & -0.19 \\
\hline \multirow[t]{2}{*}{ N8 } & 13.2 & -3.2 & 10.2 & 17.5 & -16.6 & 2.4 & 33.8 & -5.8 & 28.1 \\
\hline & 0.04 & -0.33 & 0.13 & 0.1 & -0.37 & -0.32 & 0.65 & -0.14 & 0.23 \\
\hline \multirow[t]{2}{*}{ N9 } & 17.8 & 30.6 & -20.5 & 5.3 & 3.6 & 14.9 & -14.5 & -7.0 & 40.0 \\
\hline & 0.15 & 0.32 & -0.45 & -0.11 & 0.08 & -0.04 & -0.31 & -0.11 & 0.47 \\
\hline \multirow[t]{2}{*}{ N10 } & 30.0 & 0.0 & -7.0 & 14.3 & -2.3 & 7.0 & -18.2 & -19.1 & 0.0 \\
\hline & 0.59 & -0.11 & -0.06 & 0.24 & 0.08 & 0.02 & -0.3 & -0.27 & -0.19 \\
\hline \multirow[t]{2}{*}{ N11 } & 4.8 & 14.3 & -24.4 & -9.1 & -20.0 & -11.1 & 8.7 & -10.2 & -8.7 \\
\hline & 0.24 & 0.38 & -0.29 & -0.1 & -0.18 & -0.3 & 0.46 & 0.08 & -0.29 \\
\hline \multirow[t]{2}{*}{ N12 } & -22.0 & -7.3 & -13.6 & -2.3 & -22.7 & 22.7 & -6.7 & -12.5 & 24.4 \\
\hline & -0.42 & -0.11 & -0.13 & -0.02 & -0.25 & 0.37 & 0.07 & 0 & 0.49 \\
\hline \multirow[t]{2}{*}{ N13 } & 15.8 & 15.8 & 7.3 & 0.0 & -7.3 & 17.1 & 33.3 & -6.7 & 28.6 \\
\hline & 0.05 & -0.06 & 0.02 & -0.25 & -0.24 & -0.04 & 0.56 & -0.23 & 0.18 \\
\hline \multirow[t]{2}{*}{ N14 } & -13.0 & -13.0 & -26.5 & -12.5 & -6.1 & 6.1 & -8.0 & -13.2 & -8.0 \\
\hline & -0.06 & -0.11 & -0.32 & -0.13 & 0.28 & 0.26 & 0.14 & 0.06 & -0.11 \\
\hline \multirow[t]{2}{*}{ N15 } & -14.3 & 20.0 & 15.8 & 18.9 & -5.3 & 15.8 & -17.9 & 0.0 & -2.6 \\
\hline & -0.37 & 0.23 & 0.32 & 0.22 & 0.05 & 0.02 & -0.3 & 0.11 & -0.28 \\
\hline \multirow[t]{2}{*}{ N16 } & -10.0 & 5.0 & 11.6 & -4.8 & -25.6 & 11.6 & -22.7 & 6.4 & -4.5 \\
\hline & -0.11 & 0.07 & 0.45 & -0.05 & -0.28 & 0.12 & -0.34 & 0.38 & -0.24 \\
\hline \multirow[t]{2}{*}{ N1 7} & 18.9 & 45.9 & 35.0 & -7.7 & 10.0 & 15.0 & 17.1 & -9.1 & 31.7 \\
\hline & 0.01 & 0.39 & 0.46 & -0.55 & 0.03 & -0.23 & 0.15 & -0.35 & 0.1 \\
\hline \multirow[t]{2}{*}{ N1 8} & -30.0 & 5.0 & -2.3 & -4.8 & -16.3 & 16.3 & -9.1 & -17.0 & 0.0 \\
\hline & -0.47 & 0.18 & 0.16 & -0.08 & -0.04 & 0.32 & 0.08 & -0.1 & -0.05 \\
\hline \multirow[t]{2}{*}{ N19 } & -6.7 & 1.4 & -19.1 & 12.7 & -9.3 & -4.9 & -21.3 & -6.1 & 7.0 \\
\hline & -0.05 & 0.05 & -0.2 & 0.33 & 0.06 & -0.18 & -0.25 & 0.14 & 0.1 \\
\hline \multirow[t]{2}{*}{ N20 } & 11.1 & 14.2 & 6.8 & -3.0 & -10.7 & 38.0 & 20.5 & -7.1 & 2.4 \\
\hline & 0.03 & 0.02 & 0.08 & -0.28 & -0.23 & 0.43 & 0.39 & -0.16 & -0.29 \\
\hline
\end{tabular}


Table 5 - Estimates of total heterosis $\left(h_{i j}\right)$ for GY in two experiments (EXP 2: upper values; and EXP 3: lower values).

\begin{tabular}{|c|c|c|c|c|c|c|c|c|c|}
\hline & E1 & E2 & E3 & E4 & E5 & E6 & E7 & E8 & E9 \\
\hline \multirow[t]{2}{*}{ N1 } & 66.8 & 38.4 & 128.3 & 37.1 & 100.3 & 44.1 & 44.7 & 59.1 & 37.8 \\
\hline & 39.6 & -13.4 & 81.9 & 48.0 & 52.7 & 51.6 & 28.6 & 51.1 & 21.3 \\
\hline \multirow[t]{2}{*}{ N2 } & 35.5 & 20.4 & 33.1 & 38.5 & 32.6 & -9.1 & 3.2 & 22.6 & 9.9 \\
\hline & 51.8 & -4.6 & 59.9 & 25.9 & 36.1 & -10.0 & -5.7 & -8.3 & 0.1 \\
\hline \multirow[t]{2}{*}{ N3 } & 37.0 & 23.7 & 51.0 & 57.8 & 37.6 & 18.9 & 25.5 & 34.6 & 40.7 \\
\hline & 61.8 & -1.1 & 42.7 & 47.9 & 4.3 & 49.5 & 13.2 & 9.4 & 54.2 \\
\hline \multirow[t]{2}{*}{ N4 } & 27.3 & 17.4 & 73.5 & 28.3 & 27.2 & 3.7 & 23.4 & 5.2 & 14.0 \\
\hline & 30.5 & 40.0 & 66.0 & 20.0 & 39.1 & 17.9 & 42.8 & -2.2 & 50.4 \\
\hline \multirow[t]{2}{*}{ N5 } & 13.9 & 0.5 & 41.3 & 13.8 & 47.1 & 6.2 & 3.6 & 23.5 & 13.6 \\
\hline & 25.5 & 6.6 & 42.0 & 25.2 & 36.8 & 39.4 & 10.0 & 34.8 & 29.2 \\
\hline \multirow[t]{2}{*}{ N6 } & 25.5 & 24.7 & 64.7 & 44.1 & 89.9 & 17.0 & 24.8 & 33.5 & 18.2 \\
\hline & 10.5 & 8.4 & 79.5 & 29.8 & 39.9 & 53.0 & 34.5 & 17.7 & 46.3 \\
\hline \multirow[t]{2}{*}{ N7 } & 41.0 & 16.6 & 63.0 & 27.4 & 64.0 & 17.9 & 30.1 & 22.8 & 7.0 \\
\hline & 23.1 & 16.3 & 35.2 & 20.1 & 25.3 & 51.5 & 41.8 & 20.5 & 46.4 \\
\hline \multirow[t]{2}{*}{ N8 } & 23.7 & 27.4 & 66.2 & 22.3 & 32.0 & 14.9 & 14.0 & 28.7 & 17.8 \\
\hline & 31.9 & 24.3 & 13.5 & 43.4 & 44.1 & 2.3 & 9.4 & 5.9 & 21.1 \\
\hline \multirow[t]{2}{*}{ N9 } & 30.0 & 17.6 & 11.7 & 23.5 & 38.8 & 7.4 & 2.7 & 20.3 & 19.8 \\
\hline & 34.5 & 26.4 & 26.4 & 7.0 & 23.7 & 12.4 & 9.3 & 12.7 & 12.8 \\
\hline \multirow[t]{2}{*}{ N10 } & 38.4 & 31.8 & 48.9 & 36.4 & 14.3 & 4.6 & 17.6 & 2.0 & 21.8 \\
\hline & 30.5 & 30.3 & 58.3 & 69.0 & 60.8 & 61.0 & 27.0 & 23.4 & 60.6 \\
\hline \multirow[t]{2}{*}{ N11 } & 42.7 & 39.3 & 55.5 & 26.1 & 73.2 & 24.6 & 50.5 & 33.9 & 25.0 \\
\hline & 42.8 & 29.0 & 26.7 & 25.7 & 63.9 & 50.2 & 1.4 & -4.0 & 29.5 \\
\hline \multirow[t]{2}{*}{ N12 } & 24.6 & 29.8 & 50.2 & 18.6 & 60.1 & -20.0 & 9.6 & 12.3 & 19.0 \\
\hline & 3.8 & -5.8 & 41.8 & 17.5 & 36.4 & -23.1 & 36.7 & 22.2 & 27.0 \\
\hline \multirow[t]{2}{*}{ N13 } & 53.0 & 27.3 & 36.5 & 45.1 & 74.4 & 9.3 & 15.0 & 30.5 & 54.9 \\
\hline & 25.7 & 22.6 & 63.5 & 48.1 & 79.8 & 54.0 & 55.9 & 39.9 & 43.8 \\
\hline \multirow[t]{2}{*}{ N14 } & 97.8 & 38.3 & 132.7 & 35.9 & 138.3 & 35.3 & 27.2 & 82.5 & 85.4 \\
\hline & 105.5 & -7.7 & 114.1 & 49.2 & 59.2 & 21.7 & 34.5 & 54.3 & 59.5 \\
\hline \multirow[t]{2}{*}{ N15 } & 22.1 & 28.0 & 70.9 & 32.2 & 41.0 & 9.5 & 27.3 & 37.7 & 28.1 \\
\hline & 45.1 & 11.4 & 73.2 & -1.2 & 32.6 & 67.6 & 19.1 & 49.3 & 48.2 \\
\hline \multirow[t]{2}{*}{ N16 } & 7.0 & 8.7 & 38.2 & 26.2 & 56.1 & 2.0 & 7.6 & 15.9 & 1.0 \\
\hline & 14.3 & 11.5 & 87.1 & 33.9 & 45.5 & 58.3 & 38.6 & 21.0 & 52.0 \\
\hline \multirow[t]{2}{*}{ N17 } & 12.3 & -4.3 & 27.2 & 5.3 & 24.6 & -3.2 & 5.3 & 0.3 & -14.5 \\
\hline & 1.9 & -0.7 & 8.4 & 1.2 & 1.7 & 25.7 & 19.9 & 3.0 & 19.0 \\
\hline \multirow[t]{2}{*}{ N18 } & 11.8 & 16.6 & 48.7 & 12.3 & 16.8 & 5.2 & 3.7 & 16.7 & 7.8 \\
\hline & 20.1 & 14.9 & 1.8 & 31.7 & 29.9 & -6.8 & 0.6 & 13.5 & 7.7 \\
\hline \multirow[t]{2}{*}{ N19 } & 7.6 & 29.0 & 55.2 & 42.1 & 46.5 & 0.8 & 4.0 & 25.6 & -10.7 \\
\hline & 40.7 & -0.2 & 41.5 & 45.6 & 32.8 & 45.2 & 7.6 & 7.4 & 0.4 \\
\hline \multirow[t]{2}{*}{ N20 } & 54.3 & 23.0 & 66.2 & 39.2 & 59.8 & 12.7 & 26.8 & 48.2 & 54.8 \\
\hline & 50.3 & 12.0 & 44.3 & 35.3 & 36.5 & 27.9 & 20.5 & 36.4 & 26.9 \\
\hline
\end{tabular}

$\mathrm{h}_{\mathrm{ij}}$ : expressed in percent of mid-parent.

Group 2, E1 showed a low performance for GCA while E2 were among the best ones for this effect. In EXP 3, $\mathrm{N} 18$ and E2 were oustanding for GCA, while N4 and E1 were among the poorest ones.

Finally, when considering the general performance for GY in crosses, N4 and E1 should be discarded among the populations selected for RFA. Therefore, N15, N18 and E2 are recommended as the most promising for incorporation in breeding programs, as indicated by their good level of resistance to $S$. frugiperda and acceptable agronomic traits. For plant height, $\mathrm{N} 15$ and E2 showed negative values for GCA and should be indicated as source of genotypes to lower plant architecture.

Selection of specific crosses also can be done from the presented results. High specific heterosis for both RFA and GY were shown by crosses N17 (PMI9401) x E8
(Cuba $110 \times$ ESALQ PB1) and N18 (São José) x E1 (MIRT). Total heterosis in percent of mid-parent in these crosses were $9 \%$ and $27 \%$ for RLC and $26 \%$ and $24 \%$ for GY, respectively, the indicated crosses for their properties can be used directly for the exploitation of heterosis in reciprocal recurrent selection programs, or as base for the development of inbred lines to be used in crosses.

\section{ACKNOWLEDGES}

To FAPESP for financial support.

\section{REFERENCES}

BARRIGA, P.; VENCOVSKY, R. Heterose da produção de grãos e de outros caracteres agronômicos em cruzamentos intervarietais de milho. Ciência e Cultura, v.25, p.880-885, 1973. 
Table 6 - Estimates of components of the diallel model and their variances and estimates of general combining ability $\left(g_{i}\right.$ and g) for RFA, and PH.

\begin{tabular}{|c|c|c|c|c|c|c|}
\hline \multirow[b]{2}{*}{ Group I } & \multicolumn{3}{|c|}{ Resistance to fall armyworm } & \multicolumn{3}{|c|}{ Plant height } \\
\hline & $v_{i}$ & $h_{i}$ & $g_{i}$ & $v_{i}$ & $h_{i}$ & $g_{i}$ \\
\hline N1 & 0.181 & -0.126 & -0.036 & -7.23 & 4.93 & 1.32 \\
\hline N2 & 0.304 & -0.117 & 0.035 & -5.98 & -1.93 & -4.92 \\
\hline N3 & -0.543 & 0.216 & -0.056 & 2.94 & 3.68 & 5.14 \\
\hline N4 & -0.212 & -0.150 & -0.256 & -13.48 & 5.35 & -1.39 \\
\hline N5 & -0.049 & -0.050 & -0.075 & -5.48 & -1.83 & -4.57 \\
\hline N6 & 0.346 & -0.083 & 0.090 & 7.81 & -5.50 & -1.59 \\
\hline N7 & 0.706 & -0.237 & 0.116 & -6.61 & -0.54 & -3.85 \\
\hline N8 & -0.214 & 0.204 & 0.097 & -5.48 & -0.26 & -3.00 \\
\hline N9 & -0.403 & 0.165 & -0.036 & 0.10 & -0.68 & -0.63 \\
\hline N10 & -0.058 & 0.027 & -0.003 & -6.48 & -4.29 & -7.53 \\
\hline N11 & 0.175 & -0.099 & -0.012 & 1.35 & -0.87 & -0.20 \\
\hline N12 & 0.117 & -0.077 & -0.019 & 48.19 & -0.72 & 23.37 \\
\hline N13 & -0.195 & 0.245 & 0.148 & -4.40 & 0.23 & -1.97 \\
\hline N1 4 & 0.634 & -0.253 & 0.064 & -25.98 & 23.22 & 10.23 \\
\hline N15 & -0.526 & 0.078 & -0.185 & 1.77 & -4.21 & -3.32 \\
\hline N1 6 & 0.003 & -0.063 & -0.061 & -0.44 & -4.05 & -4.27 \\
\hline N17 & -0.274 & 0.361 & 0.224 & 11.94 & -3.25 & 2.72 \\
\hline N1 8 & -0.039 & -0.094 & -0.114 & 22.69 & -4.11 & 7.23 \\
\hline N19 & 0.225 & -0.113 & 0.000 & -23.82 & -0.45 & -12.36 \\
\hline N20 & -0.179 & 0.167 & 0.077 & 8.60 & -4.72 & -0.42 \\
\hline Variance & 0.0395 & 0.0143 & $-\cdots$ & 24.95 & 9.01 & --- \\
\hline Group II & $v_{i}$ & $h_{i}$ & $g_{j}$ & $v_{i}$ & $h_{i}$ & $g_{i}$ \\
\hline $\mathrm{E} 1$ & -0.332 & 0.049 & -0.116 & -21.26 & -0.85 & -11.48 \\
\hline E2 & -0.267 & 0.081 & -0.052 & 0.08 & -9.83 & -9.79 \\
\hline E3 & -0.006 & -0.094 & -0.097 & -21.17 & 5.79 & -4.79 \\
\hline E4 & -0.044 & 0.040 & 0.018 & -4.63 & -0.38 & -2.70 \\
\hline E5 & 0.001 & -0.150 & -0.149 & -38.38 & 8.57 & -10.62 \\
\hline E6 & 0.018 & 0.182 & 0.191 & 30.28 & 8.74 & 23.88 \\
\hline E7 & 0.112 & -0.125 & -0.069 & 35.12 & -5.92 & 11.64 \\
\hline E8 & 0.448 & -0.184 & 0.040 & 20.66 & 0.07 & 10.40 \\
\hline \multirow[t]{2}{*}{ E9 } & 0.070 & 0.201 & 0.236 & -0.67 & -6.21 & -6.55 \\
\hline & 0.037 & 0.011 & --- & 23.34 & 7.00 & --- \\
\hline$\mu$ & & 2.145 & & & 186.16 & \\
\hline d & & 0.162 & & & 0.15 & \\
\hline$\overline{\mathrm{h}}$ & & -0.022 & $(1.03 \%)$ & & 7.53 & $(4.0$ \\
\hline
\end{tabular}

BELLUCI, A.A. Avaliação de populações derivadas de híbridos de milho (Zea mays L.) em cruzamentos dialélicos e "top crosses". Piracicaba, 1994 131p. Dissertação (Mestrado) - Escola Superior de Agricultura "Luiz de Queiroz", Universidade de São Paulo.

CARVALHO, R.P.L. Danos, flutuação da população, controle e comportamento de Spodoptera frugiperda (J.E.Smith, 1797) e suscetibilidade de diferentes genótipos de milho, em condições de campo. Piracicaba, 1970. 170p. Tese (Doutorado) - Escola Superior de Agricultura "Luiz de Queiroz", Universidade de São Paulo.

CASTRO, M.; GARDNER, C.O.; LONNQUIST, J.H. Cumulative gene effects and the nature of heterosis in maize crosses involving genetically diverse races. Crop Science, v.8. p.97-101, 1968

CRUZ, I. A lagarta do cartucho na cultura do milho. Sete Lagoas: EMBRAPA CNPMS, 1995. 45p. (Circular Técnica 21).

DAVIS, F.M.; NG, S.S.; WILLIAMS, W.P. Visual rating scales for screening whorl-stage corn for resistance to fall armyworm. Mississippi Agricultural and Forestry Experiment Station, 1992. (Technical Bulletin, 186).

FORNASIERI FILHO, D.; CASAGRANDE, A.A.; LARA, F.M. Resistência de cultivares de milho a $S$. frugiperda. In: CONGRESSO BRASILEIRO DE ENTOMOLOGIA, 6., Campinas, 1980. Resumos. Campinas, CECORT, CATI, 1980, p.142.

GARDNER, C.O.; EBERHART, S.A. Analysis and interpretation of the variety cross diallel and the related populations. Biometrics, v.22, p.439-452, 1966.

GERALDI, I.O.; MIRANDA FILHO, J.B. Adapted models for the analysis of combining ability of varieies in partial diallel crosses. Revista Brasileira de Genética, v.11, p.419-430, 1988.

GUIMARÃES, P.E.; VIANA, P.A. Estudo da herança da resistência de genótipos de milho ao ataque da lagarta do cartucho. Sete Lagoas: EMBRAPA, CNPMS, 1994. p.201-202. (Relatório Técnico Anual).
HALLAUER, A.R.; MIRANDA FILHO, J.B. Quantitative genetics in maize breeding. 2.ed. Ames: lowa State University Press, 1995. 468p.

LARA, F.M.; OSUNA, J.A.; ABDELNUR JR., O. Comportamento de genótipos de milho em relação ao ataque de $S$. frugiperda e $H$. Zea. Científica, v.12, p.77-83, 1984

MARQUES, C.A.S.; CAMARGO, O.B.A.; OSUNA, J.A. Avaliação fenotípica de populações de milho, sob condições de seca para os danos de $\mathrm{H}$. Zea e S. frugiperda, e outras características agronômicas. In: CONGRESSO NACIONAL DE MILHO E SORGO, 16., Belo Horizonte, 1988. Anais: EMBRAPA, CNPMS, 1988. p.327-336.

MIRANDA FILHO, J.B. Inbreeding depression and heterosis. In: COORS, J.G.; PANDEY, S. (Ed.) Genetic and exploitation of heterosis in crops. Madison: ASA. 1999. p.69-80.

MIRANDA FILHO, J.B.; GERALDI, I.O. An adapted model for the analysis of partial diallel crosses. Revista Brasileira de Genética, v.7, p.677-688. 1984.

MIRANDA FILHO, J.B.; VENCOVSKY, R. Analisys of diallel crosses among open pollinated varieties of maize (Zea mays L.). Maydica, v.29, p.217234. 1984

NISHIKAWA, M.A.N. Análise genética de populações de milho (Zea mays L.) visando resistência à lagarta do cartucho (Spodoptera frugiperda S.). Piracicaba, 1999. 90p. Tese (Doutorado) - Escola Superior de Agricultura "Luiz de Queiroz", Universidade de São Paulo.

ORTEGA, A.; VASAL, S.K.; MIHM, J.A.; HERSHEY, C. Breeding for insect resistance in maize. In: MAXWELL, F.G.; JENNINGS, P.R. (Ed.). Breeding plants resistant to insects. New Jork: John Wiley and Sons, 1980. p.371419.

REGITANO NETO, A.; MIRANDA FILHO, J.B. 1999. Incorporation of exotic germplasm of maize. (Zea mays L.). Genetics and Molecular Biology, v.22, p.702, 1999. Supplement. 
Table 7 - Estimates of components of the diallel model and their variances and estimates of general combining ability $\left(g_{i}\right.$ and $\mathrm{g}_{\mathrm{i}}$ ) for GY in two experiments.

\begin{tabular}{|c|c|c|c|c|c|c|}
\hline \multirow[b]{2}{*}{ Group I } & \multicolumn{3}{|c|}{ Exp 2} & \multicolumn{3}{|c|}{ Exp 3} \\
\hline & $v_{i}$ & $h_{i}$ & $g_{i}$ & $v_{i}$ & $\mathrm{~h}_{\mathrm{i}}$ & $g_{i}$ \\
\hline $\mathrm{N} 1$ & -2044 & 442 & -579 & -1162 & 65 & -515 \\
\hline N2 & -811 & -409 & -815 & 130 & -405 & -339 \\
\hline N3 & 343 & 308 & 480 & -66 & 38 & 5 \\
\hline N4 & -236 & -242 & -360 & -366 & 56 & -126 \\
\hline N5 & 1138 & -345 & 223 & 719 & 56 & 416 \\
\hline N6 & -518 & 151 & -107 & -143 & 127 & 55 \\
\hline N7 & -333 & -7 & -174 & 185 & 94 & 187 \\
\hline N8 & 118 & -77 & -18 & 522 & -142 & 119 \\
\hline N9 & 877 & -300 & 138 & 259 & -273 & -143 \\
\hline N10 & -78 & -209 & -248 & -506 & 380 & 126 \\
\hline N11 & -178 & 343 & 254 & 126 & 8 & 72 \\
\hline N12 & 710 & -223 & 131 & -51 & -345 & -371 \\
\hline N13 & -997 & 87 & -411 & -1006 & 302 & -200 \\
\hline N14 & -1653 & 876 & 49 & -1188 & 355 & -239 \\
\hline N15 & 218 & 118 & 227 & -21 & 55 & 44 \\
\hline N16 & 577 & -279 & 9 & -329 & 84 & -80 \\
\hline N17 & 1324 & -277 & 384 & 1393 & -161 & 534 \\
\hline N18 & 863 & -234 & 197 & 1126 & -311 & 252 \\
\hline N19 & 221 & -253 & -142 & 178 & -115 & -26 \\
\hline $\mathrm{N} 20$ & 457 & 533 & 762 & 200 & 129 & 229 \\
\hline Variance & 105826 & 38215 & --- & 134501 & 48570 & --- \\
\hline Group II & $v_{i}$ & $h_{i}$ & $g_{i}$ & $v_{i}$ & $h_{i}$ & $g_{i}$ \\
\hline E1 & -361 & 79 & -101 & -222 & 113 & 2 \\
\hline E2 & 736 & -123 & 244 & 1011 & -314 & 191 \\
\hline E3 & -980 & 674 & 184 & -1137 & 354 & -213 \\
\hline E4 & 1027 & 254 & 768 & 433 & 66 & 282 \\
\hline E5 & -1616 & 409 & -399 & -829 & 139 & -275 \\
\hline E6 & 727 & -704 & -340 & -140 & 44 & -25 \\
\hline E7 & 175 & -381 & -294 & 600 & -118 & 181 \\
\hline E8 & 550 & 44 & 319 & 1066 & -158 & 374 \\
\hline E9 & -258 & -251 & -380 & -781 & -127 & -517 \\
\hline Variance & 99018 & 29705 & --- & 125849 & 37755 & --- \\
\hline$\mu$ & & 3603 & & & 2916 & \\
\hline d & & 289 & & & 261 & \\
\hline$\overline{\mathrm{h}}$ & & 1051 & (29.2\%) & & 822 & $(28.2 \%)$ \\
\hline
\end{tabular}

SANTOS, M.X.; PACHECO, C.A.P.; GUIMARÃES, P.E.O.; GAMA, E.E.G.; SILVA, A.E.; OLIVEIRA, A.C. Diallel among twenty eight varieties of maize. Revista Brasileira de Genética. v.17, p.277-282, 1994.

SMITH, M.E; MIHM, J.A.; JEWELL, D.C. Breeding for multiple resistance to temperate, subtropical and tropical maize insect pests at CIMMYT. In: TOWARD INSECT RESISTANCE CORN FOR THE THIRD WORLD: INTERNATIONAL SYMPOSIUM ON METODOLOGIES FOR DEVELOPING HOST PLANT RESISTANCE TO CORN INSECTS, México, D.F., 1989. México, D.F.: CIMMYT, 1989. p.222-234

SOUZA Jr., C.L. Análise de cruzamentos dialélicos e predição de compostos de milho braquítico. Piracicaba, 1981. 102 p. Dissertação (Mestrado) Escola Superior de Agricultura "Luiz de Queiroz", Universidade de São Paulo.

SPRAGUE, G.F.; DAHMS, R.G. Development of crop resistance to insects. Journal of Environmental Quality, v.1, p.28-34, 1972.

VENCOVSKY, R.; BARRIGA, P. Genética biométrica no fitomelhoramento. Ribeirão Preto: Sociedade Brasileira de Genética, 1992. 486p.

VIANA, P.A.; GUIMARÃES, P.E.O. Maize resistance to the lesser corn stalk borer and fall armyworm in Brasil. In: INTERNATIONAL SYMPOSIUM: INSECT RESISTANCE MAIZE. RECENT ADVANCES AND UTILIZATION. 1994. Resumos. México:CIMMYT, 1994.

VIANA, P.A.; POTENZA, M.R. Identificação de fontes de resistência de milho a S. frugiperda. In: CONGRESSO BRASILEIRO DE ENTOMOLOGIA, 13. Recife, 1991. p.531. Resumos. Recife: SEB, 1991. v.2, p.530.

WIDSTROM, N.W.; BONDARI, K; McMILLIAN, W.W. Heterosis among insect resistance maize populations. Crop Science, v.3, p.989-994, 1993.
WIDSTROM, N.W.; WILLIAMS, W.P.; WISEMAN, B.R.; DAVIS, F.M. Recurrent selection for resistance to leaf feeding by fall armyworm on maize. Crop Science, v.32, p.1171-1174, 1992.

WILLIAMS, W.P.; BUCKLEY, P.M.; DAVIS, F.M. Combining ability for resistance in corn to fall army-warm and southwestern corn borer. Crop Science, v.29, p.913-915, 1989

WILLIAMS, W.P.; BUCKLEY, P.M.; DAVIS, F.M. Combining ability in maize for fall armyworm and southwestern corn borer resistance based on a laboratory bioassay for larval growth. Theoretical and Applied Genetics, v.90, p.275-278, 1995.

WILLIAMS, W.P.; DAVIS, F.M.; SCOTT, G.E. Resistance of corn to leaf-feeding damage by the fall armywarm. Crop Science, v.18, p.861-863, 1978.

WISEMAN, B.R; WIDSTROM, N.W. Comparison of methods of infesting whorlstage corn with fall army-worm larvae. Journal of Economical Entomolgy v.73, p.440-442, 1980.

WISEMAN, B.R.; WIDSTROM, N.W. Resistance of corn populations to larvae of the corn earworm (Lepdoptera: Noctuidae). Journal of Economical Entomolgy, v.85, p.601-605, 1992.

WISEMAN, B.R.; DAVIS, F.M.; CAMPBELL; J.E. Mechanical Infestation Device used in Fall Armyworm Plant Resistance Programs. Florida Entomologist, v.63, p.87-92, 1980.

Received September 19, 2001 